\title{
The Molecular Basis of Host Specialization in Bean Pathovars of Pseudomonas syringae
}

\author{
David A. Baltrus, ${ }^{1}$ Marc T. Nishimura, ${ }^{2}$ Kevin M. Dougherty, ${ }^{1}$ Surojit Biswas, ${ }^{2}$ M. Shahid Mukhtar, ${ }^{2}$ \\ Joana Vicente, ${ }^{3}$ Eric B. Holub, ${ }^{3}$ and Jeffery L. Dangl ${ }^{2,4,5,6,7}$ \\ ${ }^{1}$ School of Plant Sciences, The University of Arizona, PO Box 210036, Forbes Building 303, Tucson, AZ 85721-0036, \\ U.S.A.; ${ }^{2}$ Department of Biology, University of North Carolina (UNC), Chapel Hill, NC 27599 , U.S.A.; ${ }^{3}$ University of Warwick, \\ School of Life Sciences, Wellesbourne Campus, CV35 9EF, U.K.; ${ }^{4}$ Howard Hughes Medical Institute, ${ }^{5}$ Curriculum in \\ Genetics and Molecular Biology, ${ }^{6}$ Carolina Center for Genome Sciences, and ${ }^{7}$ Department of Microbiology and Immunology, \\ University of North Carolina, Chapel Hill, NC 27599, U.S.A.
}

Submitted 29 August 2011. Accepted 4 March 2012.

Biotrophic phytopathogens are typically limited to their adapted host range. In recent decades, investigations have teased apart the general molecular basis of intraspecific variation for innate immunity of plants, typically involving receptor proteins that enable perception of pathogen-associated molecular patterns or avirulence elicitors from the pathogen as triggers for defense induction. However, general consensus concerning evolutionary and molecular factors that alter host range across closely related phytopathogen isolates has been more elusive. Here, through genome comparisons and genetic manipulations, we investigate the underlying mechanisms that structure host range across closely related strains of Pseudomonas syringae isolated from different legume hosts. Although type III secretionindependent virulence factors are conserved across these three strains, we find that the presence of two genes encoding type III effectors (hopCI and hopMI) and the absence of another (avrB2) potentially contribute to host range differences between pathovars glycinea and phaseolicola. These findings reinforce the idea that a complex genetic basis underlies host range evolution in plant pathogens. This complexity is present even in host-microbe interactions featuring relatively little divergence among both hosts and their adapted pathogens.

Pseudomonas syringae is a facultative phytopathogen with the potential to cause disease in many crop species across the globe. Despite a collectively broad host range for this bacterial species, pathogen variants (pathovars) have largely been defined by their ability to cause disease in different species. Nonadapted isolates either elicit immune responses or simply fail to thrive on the incompatible host (Lindeberg et al. 2009). Individual isolates will exhibit quantitative variation in growth and symptoms both within and between host species (Fan et al. 2007; Lin and Martin 2007); thus, virulence within P. syringae is expected to be a complex trait. Although progress has been made in understanding the factors that limit and promote the

Corresponding author: D. A. Baltrus; E-mail: baltrus@email.arizona.edu

Current address: of M. S. Mukhtar: MSM Department of Biology, CH106, University of Alabama at Birmingham, 1300 University Blvd., Birmingham, AL 35294, U.S.A.

* The $\boldsymbol{e}$-Xtra logo stands for "electronic extra" and indicates that two supplementary figures and one supplementary table are published online. expansion of host range for several bacteria, there is little consensus concerning the generality and relative importance of various molecular mechanisms known to underlie host range evolution.

The host's ability to perceive and induce defense against a potential pathogen is a major barrier to plant-bacteria compatibility. For instance, the perception of pathogen- or microbeassociated molecular patterns (PAMPS or MAMPS) by matching host pattern recognition receptor (PRR) proteins is generally described as a basic layer of incompatibility because PAMPs are necessary for microbial function (e.g., flagellum or translation elongation factor) and, thus, are indispensable in the pathogen. PRR proteins induce defense responses described as PAMP- or MAMP-triggered immunity (PTI) (Jones and Dangl 2006). An additional layer of defense is provided by highly variable receptors such as nucleotide-binding leucine-rich repeat (NB-LRR) proteins, which induce defense responses described as effector-triggered immunity (ETI) (Jones and Dangl 2006). Typically, type III effectors (T3E) are the main determinants of both virulence and ETI in plant-pathogenic bacteria such as $P$. syringae (Lindeberg et al. 2009). Current opinions are divided over whether nonhost resistance (NHR), in which all tested isolates of a pathogen trigger resistance reactions in all tested cultivars of a plant species, is mechanistically different from induced immune response involving pathogen recognition (PTI and ETI) within demonstrated hosts (Abramovitch et al. 2006; Mellersh and Heath 2003; Schulze-Lefert and Panstruga 2011; Wen et al. 2010).

Mutually exclusive mechanisms for host versus NHR are difficult to prove. For instance, all bacterial cells contain multiple conserved PAMPs and, thus, are likely to trigger PTI. Virulence is expected to have evolved by an acquired ability to suppress PTI, most likely by the delivery and action of effector molecules, and specific perception of some effectors has been shown as the molecular basis for elicitation of ETI (Jones and Dangl 2006). However, plants can also contain receptors that mediate ETI to nonadapted pathogens, such as RPS4 and RPS5 proteins that could potentially protect Arabidopsis thaliana against legume pathovars of $P$. syringae in natural populations (Gassmann et al. 1999; Warren et al. 1999). Additionally, ETI-mediating receptors can provide an effective barrier of broad-spectrum resistance to a pathogen species (Borhan et al. 2008; Song et al. 2003; Tai et al. 1999; Vera Cruz et al. 2000), particularly if disruption or loss of the recognized effector significantly affects pathogen fitness on susceptible hosts. 
Both PTI and ETI can limit the growth of $P$. syringae across a wide variety of hosts (Ferrante et al. 2009; Ham et al. 2007; Li et al. 2005; Lin and Martin 2007; Perchepied et al. 2006; Takeuchi et al. 2003; Wen et al. 2010; Wroblewski et al. 2009). For example, transfer of the EFR receptor from Arabidopsis to Nicotiana benthamiana can restrict the growth of previously pathogenic strains (Lacombe et al. 2010), while diversity in flagellar proteins across strains contributes to immune evasion (Li et al. 2005; Takeuchi et al. 2003). Similarly, for ETI, the transfer of several single genes from $P$. syringae pv. tomato PT23 into various strains of $P$. syringae pv. glycinea can restrict the growth of the normally virulent recipient strain on soybean (Kobayashi et al. 1989). However, disruption of these genes within $P$. syringae pv. tomato PT23 did not increase its virulence on soybean (Lorang et al. 1994), implying either the existence of additional recognized avirulence factors or the lack of necessary virulence genes. A wide variety of strains were shown to be more virulent on a pto background of tomato (Lin and Martin 2007), which cannot recognize the T3E families avrPto or hop $A B$. Conversely, recognition of HopQ1 was shown to be the primary limitation for growth of $P$. syringae pv. tomato DC3000 on tobacco (Wei et al. 2007), and both AvrRpt2 and HopAS1 can limit the growth of multiple strains on Arabidopsis (Almeida et al. 2009; Sohn et al. 2011) . Transfer of T3E across strains has also been shown to increase the recipient's virulence on certain nonhost species (Ferrante et al. 2009; Lindeberg et al. 2009). In most if not all of these examples, the pathogen isolates used were collected from divergent host species and are distantly related. This divergence makes it difficult to place changes within an evolutionary context. Identifying molecular factors that limit growth of recently diverged strains can illuminate the molecular basis of barriers that delimit host range as well as the evolutionary path toward adaptation to new hosts.

P. syringae is a diverse bacterial species that can be phylogenetically subdivided based on DNA hybridization, multilocus sequence typing (MLST), and core genome phylogenies (Baltrus et al. 2011; Gardan et al. 1999; Hwang et al. 2005). MLST group III is composed of pathogens of numerous plant species, with a subset of isolates displaying enough diversity from other $P$. syringae clades to suggest designation as a separate species, P. savastanoi (Gardan et al. 1999; Hwang et al. 2005; Qi et al. 2011). Indeed, some members of this subgroup are metabolically less diverse than other strains, which could contribute to apparent differences in dispersion capabilities among MLST group III strains compared with other P. syringae isolates (Morris et al. 2010; Rico and Preston 2008). Such ecological differences could also provide greater opportunity for host specialization than is found in other clades of this species.

Two important pathovars within $P$. syringae MLST group III are each agronomically relevant pathogens of different legume species: P. syringae pv. glycinea causes bacterial blight of soybean (Glycine max), and P. syringae pv. phaseolicola causes halo blight in French and common dry bean (Phaseolus vulgaris) (Arnold et al. 2011; Qi et al. 2011). The interaction of isolate $P$. syringae pv. phaseolicola 1448 a with bean has been a longstanding model for understanding the basis of pathogenicity (Arnold et al. 2011). Whole genome sequences are publically available for isolates from both $P$. syringae pv. glycinea and $P$. syringae pv. phaseolicola, including strains $P$. syringae pv. glycinea R4 and $P$. syringae pv. phaseolicola 1448 a (Baltrus et al. 2011; Qi et al. 2011; Studholme 2011). Therefore, exploration of pathogenicity within this subgroup represents an important opportunity to understand host range evolution at a fine scale because of recent divergence of both the pathogens and their hosts.
Here, we report host specialization within three isolates of $P$. syringae, each collected from a different legume host and representing pathovars glycinea and phaseolicola. We added nextgeneration sequencing of isolate $P$. syringae pv. phaseolicola 1644R, (collected from mung bean) to enable comparisons of putative virulence gene repertoires with the genomes of $P$. $s y$ ringae pv. phaseolicola $1448 \mathrm{a}$ and $P$. syringae pv. glycinea $\mathrm{R} 4$. We attempted to identify molecular determinants that contribute to quantitative differences in virulence in a cultivar of Phaseolus vulgaris ('Canadian Wonder') that is susceptible to all known $P$. syringae pv. phaseolicola isolates. By placing the evolution of host range within a more narrowly defined phylogenetic context, we sought to identify molecular factors that contribute to changes in host range and to better understand the process of host range evolution.

\section{RESULTS}

Sequencing of $P$. syringae pv. phaseolicola isolate 1644R.

A draft genome sequence of $P$. syringae pv. phaseolicola $1644 \mathrm{R}$ was created by assembling one lane of Illumina PE reads with SoapDenovo ( $\mathrm{Li}$ et al. 2010). The final assembly contains 1,169 contigs with a mean contig size of 5,073 , an N50 value of 13,068 , and a maximum contig size of 66,841 . The total size of the draft genome assembly is 5,930,644 nucleotides. Using Genemark (Besemer and Borodovsky 2005), we identified a total of 6,429 nonredundant putative proteins in the draft genome, which is likely an overestimate due to its fractured nature. In all, 5,306 putative protein sequences are shared among all three strains. There are 452 putative proteins that are uniquely present within $P$. syringae pv. phaseolicola 1644R compared with these other two isolates, while 333 (approximately $16 \%, P$. syringae pv. glycinea R4) and 338 (approximately $16 \%, P$. syringae pv. phaseolicola 1448a) are missing from only one of the other strains.

\section{Fine-scale differences in host range.}

$P$. syringae pv. phaseolicola $1448 \mathrm{a}$ and $1644 \mathrm{R}$ and $P$. syringae pv. glycinea $\mathrm{R} 4$ are closely related (Fig. 1A, phylogeny) but were collected from naturally diseased leaves of three different host species: Phaseolus vulgaris (French bean), Vigna radiata (mung bean), and G. max (soybean), respectively. Additionally, P. syringae pv. phaseolicola 1644R has been assigned to race 1 within pv. phaseolicola based on differential defense reactions for multiple cultivars of French bean (data not shown). We measured growth of each of these isolates on each of the host species in order to identify finescale host specialization indicative of the early stages of host range evolution (Fig. 1B). Each bacterial isolate achieved its highest population sizes on the particular host species from which it was collected and grew to lower levels on the alternative species. Within a given host species, the isolate collected from that host grew to the highest levels. Furthermore, $P$. syringae pv. glycinea R4 grew relatively poorly on both French and mung bean while $P$. syringae pv. phaseolicola 1448a and 1644R grew to intermediate levels on mung bean and French bean, respectively. All three of these isolates grew to higher levels in French bean than most other nonbean pathogens in a phylogenetically diverse panel of bacteria (Supplementary Fig. S1).

\section{Non-type III secretion system dependent growth differences in bean pathogens.}

Suppression of PTI by hrpL-regulated virulence proteins (a subset of which are T3E) is a necessary component for successful $P$. syringae infection. To better understand the contribution of $h r p L$ - or T3E-dependent virulence effects within 
these bean pathogens and across strains, we compared growth of $h r p L$ and $h r c C$ mutants in planta across various isolates. We found that $h r p L$ and $h r c C$ mutants derived from isolate $P$. syringae pv. phaseolicola 1448a retained the ability to grow weakly in French bean leaves, and consistently achieved significantly higher population sizes in planta than comparable mutants derived from the bean pathogen $P$. syringae $\mathrm{B} 728 \mathrm{a}$ or the tomato pathogen $P$. syringae pv. tomato DC3000 (Fig. $2 \mathrm{~A}$ and $\mathrm{B})$. Additionally, although the $P$. syringae $\mathrm{B} 728 \mathrm{a}$ hrcC mutant grew to higher levels than an $h r c C$ mutant of $P$. syringae pv. tomato DC3000 (Fig. 2B), growth differences between $h r p L$ mutants of these strains were not statistically distinguishable (Fig. 2A). There was no difference in growth between $h r p L$ and $h r c C$ mutants of $P$. syringae pv. phaseolicola 1448 a (data not shown). We further found that $P$. syringae pv. glycinea R4 and $P$. syringae pv. phaseolicola $1644 \mathrm{R}$ and 1448a all shared this potential for limited growth in French bean in the absence of a functioning $h r p L$ regulon (Fig. 2B).
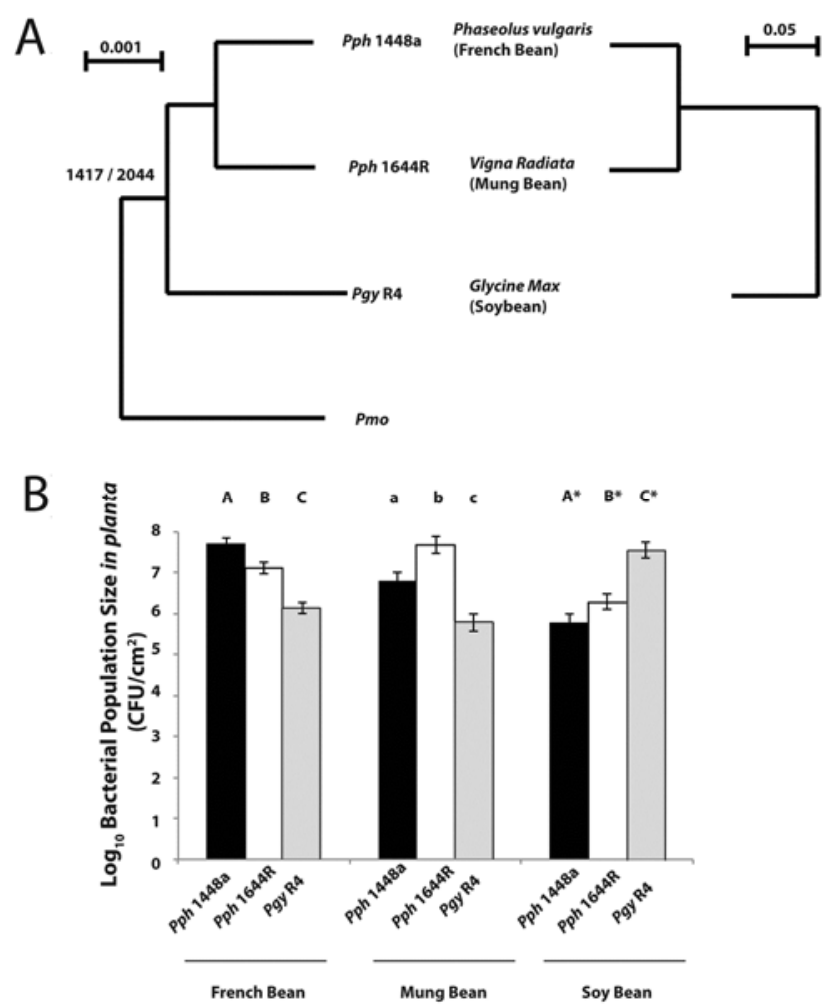

Fig. 1. Fine-scale host specialization in three bean pathogens. A, Phylogenetic relationships among all three bean pathogens based on conserved sequences within the whole genomes. Pseudomonas syringae pv. mori MAFF301020 is used as an outgroup. This Bayesian P. syringae phylogeny was constructed by analyzing sequences of 12 proteins whose evolutionary relationships match the consensus tree from genomic comparisons. The numerical label displays the fraction of individual loci phylogenies from comparisons of proteins conserved across all four strains that support these relationships. A Bayesian phylogeny of the three bean species based on $m a t K$ gene sequences is shown to the right. All nodes for the bean phylogeny had posterior probabilities $>0.95$ and are consistent with other studies (Delgado-Salinas et al. 2006; McClean et al. 2008). B, The growth of each bean pathogen isolate within three different host plants: French bean 'Canadian Wonder', mung bean, and soybean 'Merit'. Primary leaves from 2-week-old plants were syringe inoculated with bacterial suspensions and assayed 4 days (French bean, soybean) or 5 days (mung bean) after inoculation. Letters represent significant differences with $P<0.05$ according to Tukey's highly significant difference and error bars display two standard errors. Separate analyses of variance were run for each host plant data set, which is reflected by differences in the labeling scheme for statistical differences.
Comparing T3E repertoires among the bean pathogens.

We identified putative T3E within $P$. syringae pv. phaseolicola $1644 \mathrm{R}$ and compared this repertoire to those previously characterized from $P$. syringae pv. glycinea R4 and $P$. syringae pv. phaseolicola 1448a (Fig. 3A) (Baltrus et al. 2011; Chang et al. 2005; Zumaquero et al. 2010). There were 13 T3E genes shared by all three isolates, as well as one conserved truncation within hopAA1. $P$. syringae pv. phaseolicola $1644 \mathrm{R}$ and $P$. syringae pv. glycinea R4 share three T3E genes and a disrup-

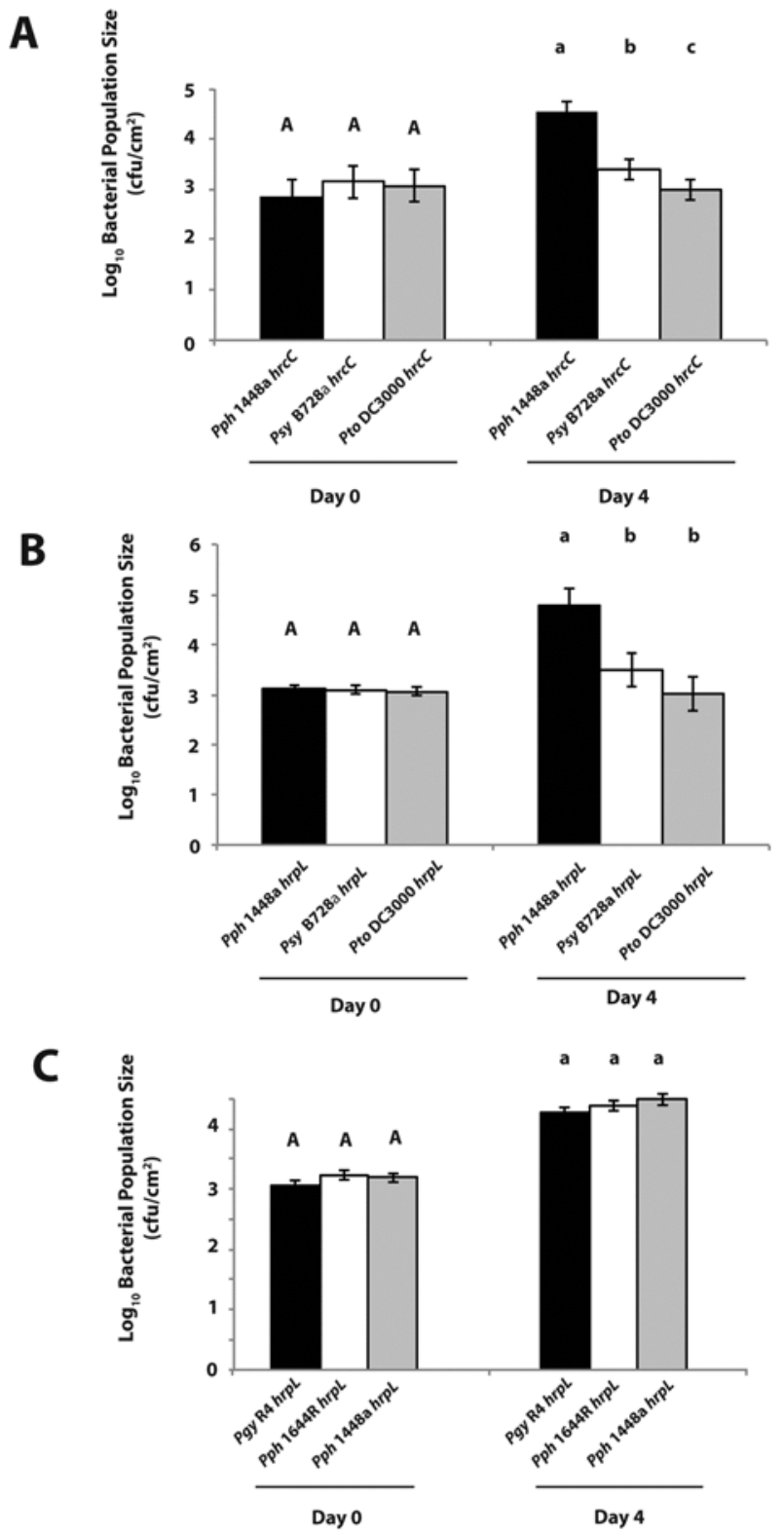

Fig. 2. Measureable type III secretion system independent virulence effects within group III bean pathogens. Bacterial population sizes for virulence mutants from several isolates were measured at day 0 and day 4 after syringe inoculation of primary leaves within 2-week-old French bean plants. A, Comparison of hrpL mutants within Pseudomonas syringae B728a, P. syringae pv. phaseolicola 1448a, and P. syringae pv. tomato DC3000. B, Comparison of hrcC mutants within P. syringae B728a, P. syringae pv. phaseolicola $1448 \mathrm{a}$, and P. syringae pv. tomato DC3000. C, Comparison of hrpL mutants of $P$. syringae pv. phaseolicola 1448a and $1644 \mathrm{R}$ and $P$. syringae pv. glycinea. Letters represent significant differences with $P<0.05$ according to Tukey's highly significant difference and error bars display two standard errors. Separate analyses of variance were run for each host plant data set, which is reflected by differences in the labeling scheme for statistical differences. 
tion within hopVl that was not found in $P$. syringae pv. phaseolicola 1448a (Fig. 3B). Conversely, P. syringae pv. phaseolicola 1644R and 1448a share four T3E genes, a truncation in hopAB3, and a C-terminus frame shift in hopMl that was not found in P. syringae pv. glycinea R4 (Fig. 3B). Only one T3E gene (hopXl) was truncated only in $P$. syringae pv. phaseolicola $1644 \mathrm{R}$, but this T3E appears to be dispensable for growth within pv. phaseolicola on French bean Canadian Wonder and we did not further characterize this locus (Stevens et al. 1998). We additionally queried the predicted protein repertoire of $P$. syringae pv. phaseolicola $1644 \mathrm{R}$ for novel T3E using the SIEVE server (McDermott et al. 2011) but found no convincing evidence for new translocated families.

\section{Testing T3E within Phaseolus vulgaris for avirulence elicitation.}

To test for phenotypic differences underlying differences in growth, French bean pods from Canadian Wonder were inoculated with all three isolates and followed for disease symptoms (Fig. 4A). P. syringae pv. phaseolicola 1448a and 1644R both caused water-soaked lesions after 3 days, whereas $P$. syringae pv. glycinea R4 elicited a browning of tissue surrounding the inoculation point, indicative of hypersensitive cell death (Tsiamis et al. 2000).

Because pod inoculations can yield variable responses, we cloned all of the T3E genes unique to $P$. syringae pv. glycinea R4 (Fig. 3), expressed them in P. syringae pv. phaseolicola 1448a under a constitutive promoter, and performed growth curves in French bean Canadian Wonder to identify potential avirulence factors underlying a hypersensitive response (HR) in the bean pod (Fig. 4B). Expression of the P. syringae pv. glycinea $\mathrm{R} 4$ allele of hopC1 in $P$. syringae pv. phaseolicola 1448a reduced growth in planta (Fig. $4 \mathrm{~B}$ and C). This is consistent with previous reports that hopCl from pv. pisi is an

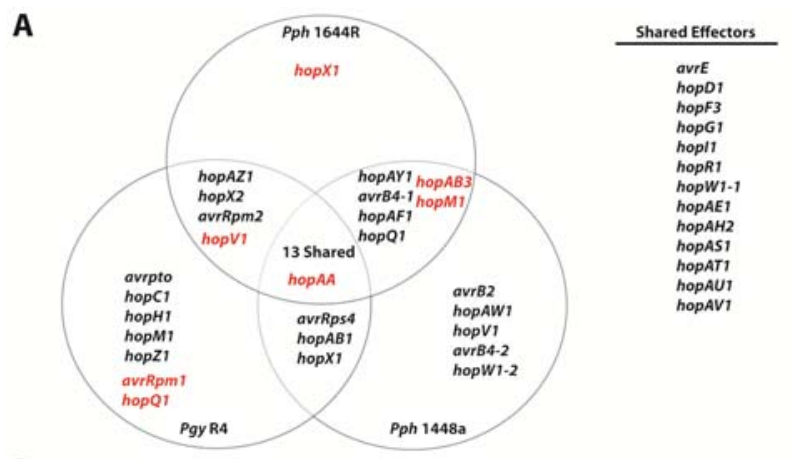

B
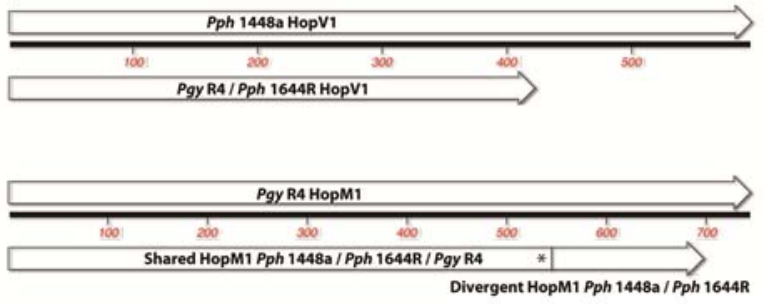

Fig. 3. Three bean isolates share similar type III effector (T3E) suites. A, The T3E suite of Pseudomonas syringae pv. phaseolicola 1644R was determined by tBLASTn, as described by Baltrus and associates (2011), and compared with $P$. syringae pv. phaseolicola $1448 \mathrm{a}$ and $P$. syringae pv. glycinea $\mathrm{R} 4$. Black letters indicate shared T3E alleles, while red letters indicate truncations in T3E compared with the other genomes. B, Diagrams of the length in amino acids of each shared truncated T3E. hopM1 from both $P$. syringae pv. phaseolicola $1448 \mathrm{a}$ and $1644 \mathrm{R}$ possesses a frame-shift mutation (represented by $*$ ) relative to the $P$. syringae pv. glycinea $\mathrm{R} 4$ nucleotide sequence, so that the $\mathrm{C}$ terminus of the proteins in both strains is truncated and diverged from that in P. syringae pv. glycinea R4. avirulence factor on all tested cultivars of French bean (Arnold et al. 2001). Similarly, expression of $P$. syringae pv. glycinea $\mathrm{R} 4$ hopM1, which was truncated in both $P$. syringae pv. phaseolicola $1448 \mathrm{a}$ and $1644 \mathrm{R}$ compared with $P$. syringae $\mathrm{pv}$. glycinea R4 (Fig. 3B), also reduced growth in French bean (Fig. 4B and C). Although expression of hopCl triggered an HR in the pod assay, hopMl did not appear to have any effect compared with wild-type $P$. syringae pv. phaseolicola 1448 a (data not shown) (Arnold et al. 2001). We found, surprisingly, that expression of avrPto from $P$. syringae pv. glycinea $\mathrm{R} 4$ increased the growth of $P$. syringae pv. phaseolicola 1448a on
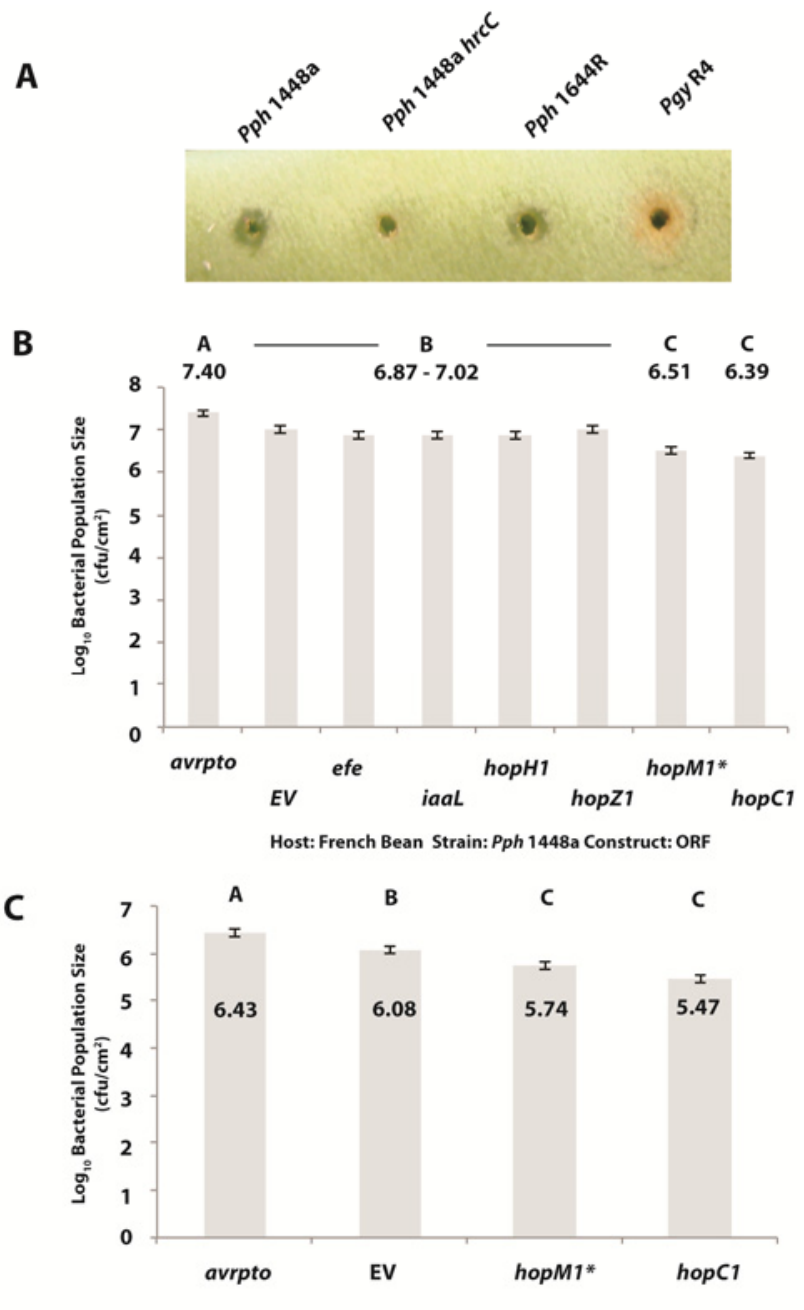

Host: French Bean Strain: Pph 1448a Construct: Gene

Fig. 4. Type III effectors (T3E) within Pseudomonas syringae pv. glycinea R4 but not $P$. syringae pv. phaseolicola $1644 \mathrm{R}$ trigger avirulence responses in French bean 'Canadian wonder'. A, The three group III bean pathogen isolates as well as an $h r c C$ - version of P. syringae pv. phaseolicola 1448a were inoculated into bean pods and observed for virulence responses. B, T3E present in $P$. syringae pv. glycinea $\mathrm{R} 4$ but absent within $P$. syringae pv. phaseolicola 1448 a were cloned as open reading frames (ORF) including stop codons and measured for their ability to affect growth of $P$. syringae pv. phaseolicola 1448a in French bean. Expression of these effectors was driven from an $n p t I I$ promoter. C, T3E that modify growth of $P$. syringae pv. phaseolicola 1448a in French bean as ORF were cloned with their native promoters and without stop codons and measured for their effects on growth of $P$. syringae pv. phaseolicola 1448a in French bean. Only two independent growth curves were performed. An asterisk (*) indicates that the effector clone includes an upstream chaperone. Primary leaves from 2-week-old plants were syringe inoculated with bacterial suspensions and assayed 4 days after inoculation. Letters represent significant differences with $P<0.05$ according to Tukey's highly significant difference and error bars display two standard errors. Growth values are listed below statistical groups, with maximum and minimum values listed for pooled groups. 
French Bean (Fig. 4B and C). We also tested two genes uniquely present in P. syringae pv. glycinea R4 known to be involved in virulence: efe and iaaL (Mazzola and White 1994; Weingart et al. 2001). The efe gene codes for ethylene-forming enzyme, which catalyzes the oxygenation of 2-oxoglutarate to form ethylene (Weingart et al. 2001), while the protein product of iaaL metabolizes indole acetic acid (auxin) to 3-indole-acetylL-lysine (Glickmann et al. 1998). Neither altered the growth of $P$. syringae pv. phaseolicola 1448 a on French bean. Finally, we note that, although both $P$. syringae pv. glycinea $\mathrm{R} 4$ and $P$. syringae pv. phaseolicola $1644 \mathrm{R}$ appeared to lack the pathway for production of phaseolotoxin, absence of this virulence factor has not been shown to alter bacterial growth in planta (Patil et al. 1974).

\section{Identifying virulence factors that enhance growth on French bean.}

We generated a mutant of $P$. syringae pv. glycinea R4 (DAB890) in which both copies of the hopH1/hopCl locus and hopMl (the genes identified above conferring avirulence on French bean Canadian Wonder) were all deleted from the genome. This mutant did not exhibit altered growth on French bean Canadian Wonder (Fig. 5A) and still appeared to trigger an HR-like response in pod assays (data not shown). We then replaced T3E genes that were present in $P$. syringae pv. phaseolicola 1448a but absent from $P$. syringae pv. glycinea R4 (Fig. 3) into DAB890, and tested the resulting strains for their ability to increase the growth of the mutant on French bean Canadian Wonder. Only the expression of avrB2 increased the growth of DAB890 (Fig. 5A). A similar effect but with smaller magnitude was observed when $a v r B 2$ from $P$. syringae pv. phaseolicola 1448 a was expressed from its native promoter in the wild-type $P$. syringae pv. glycinea R4 background (Fig. 5C). We also moved T3E genes that were present in $P$. syringae pv. phaseolicola 1448 a but not $P$. syringae pv. phaseolicola 1644R (Fig. 3) into P. syringae pv. phaseolicola $1644 \mathrm{R}$; none consistently increased the growth of $P$. syringae pv. phaseolicola 1644R on French bean Canadian Wonder (Fig. 5D).

\section{DISCUSSION}

Many studies have focused attention on characterizing the molecular basis of NHR to phytopathogens (Mellersh and Heath 2003; Mysore and Ryu 2004; Schulze-Lefert and Panstruga 2011; Wen et al. 2010). There is often a continuum of quantitative differences in growth, persistence, or virulence for pathogens on plant genotypes that have been used in experiments to represent nonhost species (Lin and Martin 2007). Moreover, investigations of NHR often involve comparisons of virulence between pathogen isolates that have significantly diverged. The phylogenetic relationship among the isolates and the original hosts from which the isolates were collected is an important consideration for these studies.
A
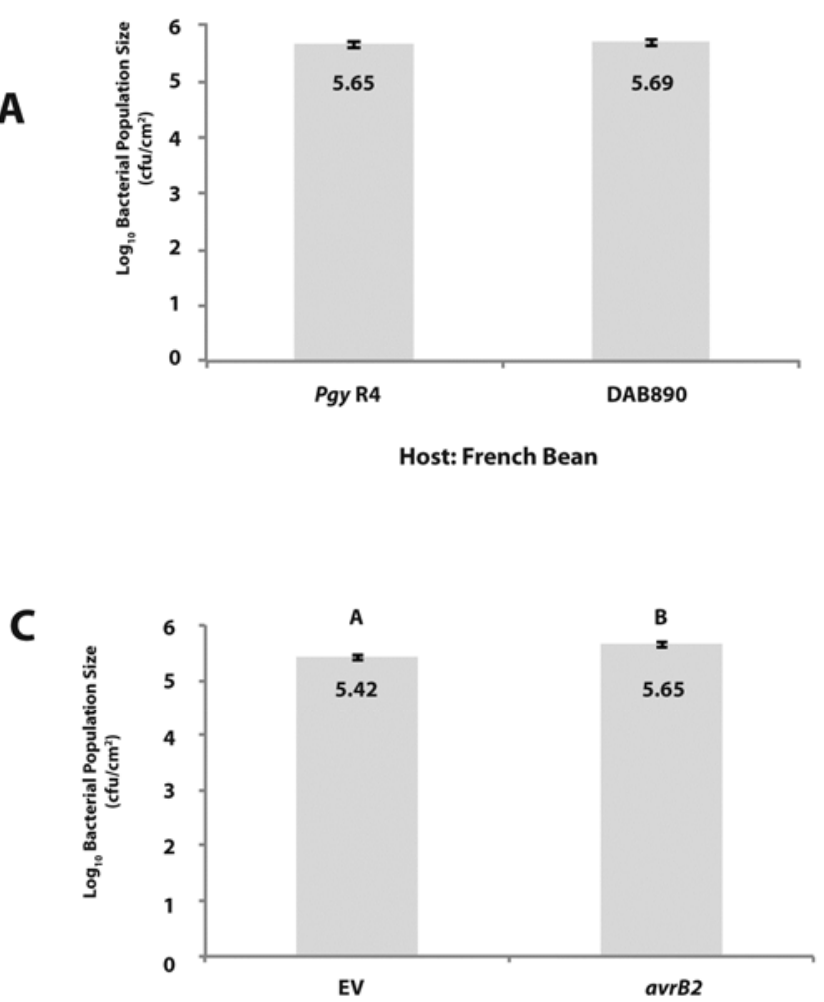

Host: French Bean Strain: Pgy R4 Construct: Gene
B

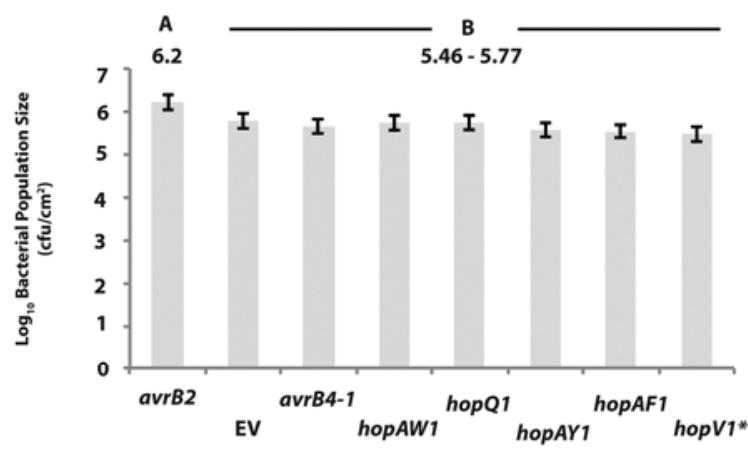

Host: French Bean Strain: DAB890 Construct: ORF

D

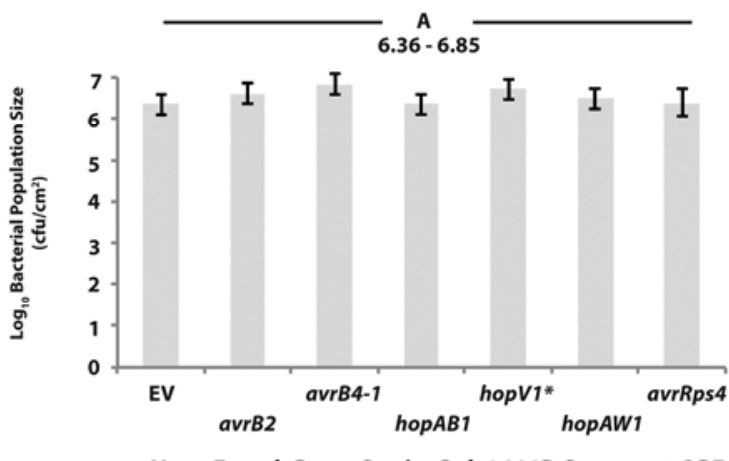

Host: French Bean Strain: Pph 1644R Construct: ORF

Fig. 5. avrB2 acts as a virulence factor on French bean for Pseudomonas syringae pv. glycinea R4. A, Deletion of hopC1, hopH1, and hopM1 from P. syringae pv. glycinea $R 4$ does not affect growth on French bean. B, Type III effectors (T3E) present in $P$. syringae pv. phaseolicola 1448 a but absent within $P$. syringae pv. glycinea $\mathrm{R} 4$ were cloned as open reading frames (ORF) with stop codons and measured for their ability to modify growth of DAB890 in French bean. C, avrB2 was cloned with its native promoter and without stop codons and measured for its ability to modify growth of $P$. syringae pv. phaseolicola 1448a in French bean. D, T3E present in $P$. syringae pv. phaseolicola 1448a but absent within $P$. syringae pv. phaseolicola 1644R were cloned as ORF with stop codons and measured for their ability to affect growth of $P$. syringae pv. phaseolicola $1644 \mathrm{R}$ in French bean. An asterisk (*) indicates that the effector clone includes an upstream chaperone. Primary leaves from 2-week-old plants were syringe inoculated with bacterial suspensions and assayed 4 days after inoculation. Letters represent significant differences with $P<0.05$ according to Tukey's highly significant difference and error bars display two standard errors. Growth values are listed below statistical groups, with maximum and minimum values listed for pooled groups. 
Given the rapid advances in DNA sequencing, it is now feasible and straightforward to compare suites of virulence factors between pathogen isolates. Such comparisons will be most informative between closely related bacterial isolates that differ quantitatively in their respective ability to grow on recently diverged host species. This approach allows one to phylogenetically trace the early steps of host range specialization and enables identification of molecular differences that may ultimately contribute to NHR. Conversely, a better understanding of molecular barriers that delimit host range will provide insight into the evolutionary potential for host shifts of these pathogens to new plant species.

With this approach in mind, we chose three recently diverged $P$. syringae isolates collected from closely related legume species to explore the evolution of pathogenicity. Three strains $(P$. syringae pv. phaseolicola $1448 \mathrm{a}$ and $1644 \mathrm{R}$ and $P$. syringae pv. glycinea R4) were originally isolated from naturally diseased leaves of Phaseolus vulgaris (French bean), V. radiata (mung bean), and G. max (soybean), respectively (Arnold et al. 2011; Baltrus et al. 2011; Marques et al. 2000). The legume hosts are estimated to have diverged from each other within the last 20 million years, and their genomes display a high level of similarity and colinearity (Delgado-Salinas et al. 2006; McClean et al. 2008). The demographic and evolutionary history of the three bacterial isolates is unknown; however, their phylogenetic branching pattern mirrors that of their respective host species, suggesting co-evolution of pathovars with host species (Fig. 1A). We observed quantitative differences in host specialization, such that each isolate grew best on its original host and slightly less on the other two hosts. All three bacterial strains exhibited higher levels of growth on French bean than did a majority of phylogenetically diverse $P$. syringae isolates.

Given the common occurrence of genotype-host interactions in this pathosystem (Taylor et al. 1996), the molecular mechanisms that define host range differences between pathovars are difficult to determine without extensive sampling of multiple combinations of strains and cultivars. Such studies are complicated by subjective decisions in defining host range, such as interpreting subtle phenotypic variation in symptoms that could indicate partial overlap of host ranges. However, to enable progress with the Pseudomonas-legume pathosystem, we chose cultivars of each host plant (except mung bean) that are fully susceptible to all defined races of each particular pathovar in order to limit the influence of ETI. Conversely, $P$. syringae $\mathrm{pv}$. phaseolicola $1448 \mathrm{a}$ and $P$. syringae $\mathrm{pv}$. glycinea R4 are also virulent on all tested cultivars of French bean and soybean, respectively. Although the magnitude of differences between these isolates may change in a cultivar-dependent way, we focused on the virulence potential of each isolate on a particular host and highlight changes with the potential to modify host range between these isolates.

As noted in the introduction, NHR is considered to be a complex phenotype involving defense induced by recognition of either PAMPs or translocated effector proteins. The fact that hrpL and hrcC mutants of $P$. syringae pv. phaseolicola $1448 \mathrm{a}$ grew to higher levels than mutant counterparts from either $P$. syringae pv. tomato DC3000 (a tomato pathogen) or P. syringae B728a (a distantly related bean pathogen) on French bean demonstrates that $P$. syringae pv. phaseolicola 1448a has adapted to its bean host in an hrpL-and type III secretionindependent manner (Fig. 2A), and also suggests a fundamental difference in virulence mechanisms on the same host between two well-studied isolates of pvs. phaseolicola and syringae. It is possible that $P$. syringae pv. phaseolicola 1448a PAMPs have evolved to better evade recognition by bean PRR, although the full complement of $P$. syringae pv. phaseolicola 1448a T3E may still be weakly recognized and generate basal defenses on French bean. P. syringae pv. phaseolicola 1448a may also be better adapted to use nutrients or survive within the bean apoplast, even in the absence of a type III secretion system. Nevertheless, these growth differences are hrpL independent, likely gacAS independent (Ortiz-Martín et al. 2010), and at least partially conserved in $P$. syringae pv. phaseolicola 1644R and P. syringae pv. glycinea R4 (Fig. 2B). Comparisons of signatures of evolution within the genomes of these isolates in connection with measurement of growth $h r p L$ mutants for other group III isolates could allow for identification of additional virulence factors.

Although both $P$. syringae pv. glycinea $\mathrm{R} 4$ and $P$. syringae pv. phaseolicola $1644 \mathrm{R}$ grew more poorly than $P$. syringae $\mathrm{pv}$. phaseolicola 1448a on French bean, only P. syringae pv. glycinea $\mathrm{R} 4$ triggered a hypersensitive cell death response when inoculated into French bean pods (Fig. 4A). ETI has previously been shown to contribute to NHR across closely related strains (Almeida et al. 2009). Thus, we sought to identify avirulence factors from this isolate by cloning all T3E from $P$. syringae pv. glycinea $\mathrm{R} 4$ that are not found within $P$. syringae pv. phaseolicola $1644 \mathrm{R}$ or $1448 \mathrm{a}$, and determining whether these T3E affected growth when expressed in $P$. syringae pv. phaseolicola 1448a. Arnold and associates (2001) have previously shown that the hopC1 allele from $P$. syringae pv. pisi acts as an avirulence factor on all French bean cultivars tested. Therefore, it is not surprising that the $P$. syringae pv. glycinea R4 allele of hopCl was recognized by French bean Canadian Wonder. $P$. syringae pv. glycinea $\mathrm{R} 4$ contains two copies of the hopC1/hopH1 locus (Baltrus et al. 2011), and this locus is absent from all other known group III pathovars of $P$. syringae. This is evidence for recent acquisition by $P$. syringae pv. glycinea $\mathrm{R} 4$ and suggests that hopCl or hopH1 may play an important virulence role in some context during natural infection of soybean. However, we were unable to find a role for these genes after hand inoculation of soybean leaves under laboratory conditions; we found that $P$. syringae pv. glycinea R4 and DAB890 (in which both copies of the hopCl/hopHl operon were deleted) grew to similar levels on 'Merit' soybean (data not shown).

We also found that HopC1 can act as an avirulence factor in mung bean (Supplementary Fig. S2), suggesting conservation of a resistance gene across a wide variety of Phaseolus vulgaris cultivars as well as across legume species (Arnold et al. 2001). This may explain why $P$. syringae pv. glycinea R4 grows equally poorly on both French bean and mung bean, whereas $P$. syringae pv. phaseolicola $1644 \mathrm{R}$ grows to intermediate levels on French bean and soybean. Therefore, acquisition of hopCl could be an event that differentiates pv. glycinea from pv. phaseolicola. We also found that $P$. syringae pv. glycinea R4 contains an additional factor with potential to restrict growth in French bean, because translocation of full-length HopM1 leads to lower growth of $P$. syringae pv. phaseolicola 1448a. This is surprising because the hopM1 locus is thought to be a fundamental virulence factor present within all pathogenic strains of $P$. syringae, and is not known to be recognized by any other host plants despite being independently truncated within multiple isolates, (Baltrus et al. 2011; Cai et al. 2011).

Despite being the least virulent of our three isolates on the tested cultivars of French bean and mung bean, $P$. syringae pv. glycinea R4 contains a T3E ( $a v r P t o$ ) that increases growth of $P$. syringae pv. phaseolicola 1448a on French bean Canadian Wonder (Fig. 4). Because AvrPto suppresses upstream steps in plant defense by binding to and inhibiting the action of the FLS2BAK PRR complex (Xiang et al. 2008), this could indicate that $P$. syringae pv. phaseolicola 1448 a growth is ultimately still limited by the French bean immune system in a way that is not overcome by its repertoire of T3E. It is also possible that the $P$. 
syringae pv. glycinea R4 allele of avrPto acts more rapidly than the $P$. syringae pv. phaseolicola 1448a T3E suite to block plant defenses, or masks "weak" ETI dependent on recognition of a T3E. The possibility of weak ETI constraining multiplication of virulent pathogens has been reported previously. For example, $P$. syringae pv. tomato DC3000 grows to higher levels on rar1-21 Arabidopsis plants and RAR1 functions only as a chaperone to stabilize steady-state levels of the NB-LRR receptors required for ETI (Holt et al. 2005).

This result is intriguing because $P$. syringae pv. phaseolicola 1448a contains an active version of hopAB1, alleles of which have been shown to target the FLS2-BAK PRR complex (Shan et al. 2008). HopAB1 is considered part of the same redundant effector group (REG) as AvrPto and, thus, thought to suppress the same level of the plant immune response (Cunnac et al. 2011). Although components of an REG may act somewhat independently to disrupt conserved defense pathways, evolutionary divergence may also result in different roles for these T3E in different host contexts. That avrPto-hopAB2 affect similar defense pathways in Arabidopsis and tomato does not necessarily mean that avrPto-hopAB1 have the same functions in French bean or soybean. Similar to hopCl, this allele of avrPto appears to be a recent import into $P$. syringae pv. glycinea R4 because it is not present within any other group III isolate and may signal differences in virulence strategies between pvs. glycinea and phaseolicola.

Disruption of all avirulence genes identified above from $P$. syringae pv. glycinea $\mathrm{R} 4$ for French bean Canadian Wonder did not increase growth of this isolate on this host (Fig. 5A). Therefore, growth differences between $P$. syringae pv. glycinea $\mathrm{R} 4$ and $P$. syringae pv. phaseolicola 1448a must be explained by the presence of additional avirulence factors or the absence of virulence factors (Lorang et al. 1994). To explore these possibilities, we singly added all T3E present in $P$. syringae pv. phaseolicola 1448 a but absent in $P$. syringae pv. glycinea R4 to strain DAB890 (P. syringae pv. glycinea R4 in which the hopC1-hopHl operons and hopMl have been deleted) and measured growth on French bean Canadian Wonder.

AvrB2 from P. syringae pv. phaseolicola 1448a did increase growth of this isolate on French bean (Fig. 5B and C). This difference is consistent, although more subtle, when expression of avrB2 was driven by its native promoter within $P$. syringae pv. glycinea R4 containing the resident two copies of hopCl as well as hopM1. AvrB2 has previously been shown to mask the avirulence effect of HopF1 in French bean within P. syringae pv. phaseolicola 1449b (Tsiamis et al. 2000) but hopFl is absent from $P$. syringae pv. glycinea R4. Furthermore, avrB2 does not appear to increase the growth of $P$. syringae pv. phaseolicola 1644R on French bean (Fig. 5D), so that the virulence function of this T3E is either compensated for by other virulence genes within $P$. syringae pv. phaseolicola $1644 \mathrm{R}$ or is epistatic to an alternative $P$. syringae pv. glycinea $\mathrm{R} 4$ specific factor.

It has recently been proposed that the dominant mode of recognition progresses from ETI to PTI as the phylogenetic divergence between host species increases (Schulze-Lefert and Panstruga 2011). In this comparison between three closely related isolates, recognition of T3E plays a limited role over relatively short divergence times because there is no evidence that P. syringae pv. phaseolicola 1644R contains T3E recognized by French bean (Fig. 4A). Moreover, absence of single T3E does not explain the virulence deficit for $P$. syringae pv. phaseolicola 1644R (Fig. 5D). Further investigation will explore whether allelic differences and expression differences in the T3E suites or differences in metabolic capabilities between these two isolates contributes toward adaptation to their respective hosts of isolation. Over longer time scales ( $P$. syringae pv. glycinea R4 to $P$. syringae pv. phaseolicola $1448 \mathrm{a}$ ), there are multiple events leading to recognition of $P$. syringae pv. glycinea $\mathrm{R} 4$ on French bean. Although acquisition of HopC1 by $P$. syringae pv. glycinea R4 limits growth on both French bean and mung bean, the default state for many $P$. syringae strains on French bean may be NHR due to recognition of the conserved T3E hopM1. Taken as a whole, our study suggests that the comparisons of whole genome sequences within a phylogenetic context can provide insight into fine-scale host range differences, and that some of the functional complexity of host range evolution in plant-microbe interactions can be observed even among closely related host and pathogen species.

\section{MATERIALS AND METHODS}

Plasmids, bacterial isolates, and growth conditions.

All plasmids used or created are listed in Table 1, while the bacterial isolates are listed in Table 2. Typically, $P$. syringae isolates were grown at $27^{\circ} \mathrm{C}$ on King's B (KB) media using rifampicin at $50 \mu \mathrm{g} / \mathrm{ml}$. When necessary, cultures of both $P$. syringae and Escherichia coli were supplemented with antibiotics or sugars in the following concentrations: tetracycline at 10 $\mu \mathrm{g} / \mathrm{ml}$, kanamycin at $50 \mu \mathrm{g} / \mathrm{ml}$, gentamycin at $25 \mu \mathrm{g} / \mathrm{ml}$, and $5 \%$ sucrose.

All clones were created by first amplifying target sequences using Pfx polymerase (Invitrogen, Carlsbad, CA, U.S.A.), followed by recombination of these fragments into the entry vector pDONR207 using BP clonase (Invitrogen). All open reading frame (ORF) (without an $h r p$-box promoter) and gene (including the promoter) sequences were confirmed by Sanger sequencing of these pDONR207 clones. ORF clones always included stop codons at the end of the sequence but gene clones did not, and the start codons for all ORF sequences were based on previous annotations, comparison across alleles, and proximity to the $h r p$ box. Known chaperones for some T3E ( $s h c M$ and $s h c V$ ) were included in both ORF and gene clones. Clones in entry vectors were recombined into destination vectors of interest using LR clonase (Invitrogen).

\section{Generation of mutants.}

Bacterial mutants were generated using a modified suicide plasmid protocol (Marco et al. 2005). Regions (>500 bp) upstream and downstream of the target genes were polymerase chain reaction (PCR) amplified separately and then combined into one fragment by overlap extension PCR. The bridge PCR amplicon was then cloned into pDONR207, and further moved into MTN1907 using LR clonase. MTN1907 is a modified version of the pLVC-D suicide plasmid (Marco et al. 2005), providing tetracycline resistance as well as sucrose counterselection from $s a c B$ cloned downstream of a trp promoter (giving constitutive $s a c B$ expression). MTN1907 also includes an nptII gene providing resistance to kanamycin but we note that expression from this locus is not consistent in $P$. syringae. Once mated into $P$. syringae, single recombination of a homologous region upstream or downstream of the target region and subsequent selection on sucrose allows for screening of clean deletions. Mutants were confirmed by phenotyping for sucrose resistance, tetracycline sensitivity, PCR amplification of the deletion, and failure of PCR to amplify regions within the deletion.

\section{Sequencing and annotation}

of $P$. syringae pv. phaseolicola $1644 \mathrm{R}$.

$P$. syringae pv. glycinea $\mathrm{R} 4$ is a race 4 isolate of $p v$. glycinea obtained from the Staskawicz lab (Baltrus et al. 2011), while the history of $P$. syringae pv. phaseolicola 1448 a is well documented (Arnold et al. 2011) and was originally collected by Habtu Assefa in Ethiopia in 1985. P. syringae pv. phaseolicola 
1644 (NCPPB 2435) was originally isolated from $V$. radiata in the United States in 1971. A rifampicin-resistant mutant of $P$. syringae pv. phaseolicola 1644 was generated through selection, and one colony of this isolate was picked and grown overnight in $250 \mathrm{ml}$ of $\mathrm{KB}$ liquid media to generate genomic DNA for sequencing. Genomic DNA was collected using the cetyltrimethylammonium bromide extraction method. One lane of sequencing on an Illumina GAII using a standard protocol for paired end library generation (yielding 18,862,298 total reads of $36 \mathrm{bp}$ ) was used to generate a draft genome sequence of $P$. syringae pv. phaseolicola 1644R. Reads were assembled de novo using SoapDenovo (Li et al. 2010) and custom Perl scripts that optimized the assembly for number of contigs and mean contig size. The best assembly was generated with a kmer size of 32 . Reads were not culled for quality before the assembly. The nucleotide sequences of contigs from this assembly can be found under GenBank accession AGAS00000000.

It is difficult to precisely annotate lower-quality draft genomes, which often contain gaps and ORF fragments. There- fore, we used a progression of scripts and filters to quantify a putative number of proteins present within $P$. syringae pv. phaseolicola $1644 \mathrm{R}$ that were absent from $P$. syringae pv. glycinea R4 or $P$. syringae pv. phaseolicola 1488a. We first used Genemark (Besemer and Borodovsky 2005) to call ORF from the draft genome, screened for ORF $>50$ amino acids, and used BLASTp versus the $P$. syringae pv. phaseolicola $1448 \mathrm{a}$ proteome (Joardar et al. 2005) (screened for exact matches in amino acid identity [AAID]) to identify proteins that were duplicated or truncated due to poor assembly quality. Once these redundant features were culled, we used BLASTp $(e$ value $=$ 1e-5, AAID $>85 \%$ ) to identify loci absent from the $P$. syringae pv. glycinea $\mathrm{R} 4$ and $P$. syringae pv. phaseolicola 1448 a proteomes (Baltrus et al. 2011). We then used tBLASTn $(e$ value $=$ 1e-5, AAID $>85 \%$ ) against both the $P$. syringae pv. glycinea $\mathrm{R} 4$ and $P$. syringae pv. phaseolicola 1448a genomes to further narrow the list of novel ORF. Finally, we used BLASTp $(e$ value $=1 \mathrm{e}-5$, no cutoff) against the NR database to screen out redundant $P$. syringae pv. phaseolicola $1644 \mathrm{R}$ ORF and create a final list of novel proteins. Although these ORF are poten-

Table 1. Strains

\begin{tabular}{|c|c|c|}
\hline Strain & Description & Reference \\
\hline Pseudomonas syringae pv. phaseolicola $1448 \mathrm{a}$ & $\begin{array}{l}\text { P. syringae pv. phaseolicola race } 6 \text { isolate, rifampicin } \\
\text { resistant }\end{array}$ & Joardar et al. 2005; Taylor et al. 1996 \\
\hline P. syringae pv. glycinea $\mathrm{R} 4$ & P. syringae pv. glycinea race 4 isolate, rifampicin resistant & Baltrus et al. 2011; Staskawicz et al. 1984 \\
\hline P. syringae $\mathrm{pv}$. phaseolicola $1644 \mathrm{R}$ & $\begin{array}{l}\text { P. syringae pv. phaseolicola race } 1 \text { isolate, rifampicin } \\
\text { resistant }\end{array}$ & This article, derived from Taylor et al. 1996 \\
\hline DAB007 & P. syringae pv. tomato DC3000 hrcC mutant & Roine et al. 1997 \\
\hline DAB087 & P. syringae pv. syringae B728a $h r c C$ mutant & Hirano et al. 1999 \\
\hline DAB093 & $\begin{array}{l}\text { P. syringae pv. phaseolicola race } 4 \text { strain } 1448 \text { a hrcC } \\
\text { mutant, rifampicin resistant }\end{array}$ & $\begin{array}{l}\text { This article, derived from Ortiz-Martin et } \\
\text { al. } 2006\end{array}$ \\
\hline DAB786 & $\begin{array}{l}\text { P. syringae pv. phaseolicola } 1448 \text { a } h r p L \text { clean deletion, } \\
\text { rifampicin resistant }\end{array}$ & This article \\
\hline DAB963 & $\begin{array}{l}\text { P. syringae pv. tomato DC } 3000 \text { hrpL clean deletion, } \\
\text { rifampicin resistant }\end{array}$ & This article \\
\hline P. syringae $\mathrm{B} 728 \mathrm{a}$ hrpL & Obtained from Dr. Gwyn Beattie & Unpublished \\
\hline DAB886 & $\begin{array}{l}\text { P. syringae pv. glycinea } \mathrm{R} 4 \text { isolate with } h r p L \text { clean } \\
\text { deletion, rifampicin resistant }\end{array}$ & This article \\
\hline DAB890 & $\begin{array}{l}\text { P. syringae pv. glycinea } \mathrm{R} 4 \text { isolate with } 2 \mathrm{x} \text { hopCl/hopH1 } \\
\text { and shcM1/hopM1 clean deletion }\end{array}$ & This article \\
\hline DAB907 & $\begin{array}{l}\text { P. syringae pv. phaseolicola } 1644 \mathrm{R} \text { with } \text { hrpL clean } \\
\text { deletion, rifampicin resistant }\end{array}$ & This article \\
\hline DAB748 & P. syringae pv. phaseolicola 1448 a with pDAB256 & This article \\
\hline DAB809 & P. syringae pv. phaseolicola 1448 a with pDAB245 & This article \\
\hline DAB784 & P. syringae pv. phaseolicola 1448 a with pDAB363 & This article \\
\hline DAB775 & P. syringae pv. phaseolicola 1448 a with pDAB267 & This article \\
\hline DAB771 & P. syringae pv. phaseolicola 1448 a with pDAB272 & This article \\
\hline DAB804 & P. syringae pv. phaseolicola 1448 a with pDAB289 & This article \\
\hline DAB774 & P. syringae pv. phaseolicola 1448 a with pDAB268 & This article \\
\hline DAB828 & P. syringae pv. phaseolicola 1448 a with pDAB296 & This article \\
\hline DAB831 & P. syringae pv. phaseolicola $1644 \mathrm{R}$ with pDAB296 & This article \\
\hline DAB767 & P. syringae pv. phaseolicola $1644 \mathrm{R}$ with pDAB269 & This article \\
\hline DAB768 & P. syringae pv. phaseolicola $1644 \mathrm{R}$ with pDAB270 & This article \\
\hline DAB799 & P. syringae pv. phaseolicola $1644 \mathrm{R}$ with $\mathrm{pDAB} 271$ & This article \\
\hline DAB806 & P. syringae pv. phaseolicola $1644 \mathrm{R}$ with $\mathrm{pDAB} 286$ & This article \\
\hline DAB750 & P. syringae pv. phaseolicola $1644 \mathrm{R}$ with $\mathrm{pDAB} 250$ & This article \\
\hline DAB830 & P. syringae pv. phaseolicola $1644 \mathrm{R}$ with pDAB254 & This article \\
\hline DAB183 & P. syringae pv. phaseolicola 1448 a with pDAB040 & This article \\
\hline DAB524 & P. syringae pv. phaseolicola 1448 a with pDAB151 & This article \\
\hline DAB182 & P. syringae pv. phaseolicola 1448 a with pDAB039 & This article \\
\hline DAB892 & P. syringae pv. phaseolicola 1448 a with $\mathrm{pDAB} 334$ & This article \\
\hline DAB954 & P. syringae pv. glycinea $\mathrm{R} 4$ with pDAB 334 & This article \\
\hline DAB960 & P. syringae pv. glycinea R4 with MTN500 & This article \\
\hline DAB939 & DAB 890 with pDAB269 & This article \\
\hline DAB943 & DAB890 with pDAB296 & This article \\
\hline DAB940 & DAB890 with pDAB270 & This article \\
\hline DAB941 & DAB890 with pDAB250 & This article \\
\hline DAB937 & DAB890 with pDAB287 & This article \\
\hline DAB936 & DAB890 with pDAB339 & This article \\
\hline DAB938 & DAB890 with pDAB341 & This article \\
\hline DAB945 & DAB890 with pDAB286 & This article \\
\hline
\end{tabular}


tially full length, we emphasize that the number of true ORF within $P$. syringae pv. phaseolicola $1644 \mathrm{R}$ may differ due to inclusions or exclusions of truncated loci as well as inclusion of noncoding regions.

\section{Phylogenetics.}

To resolve evolutionary relationships among these three isolates (and including P. syringae pv. mori MAFF301020 as an outgroup) (Baltrus et al. 2011), we created amino acid sequencebased trees using a database of 2,400 orthologous genes shared by all four isolates. We required reciprocal best hits, with $80 \%$ amino acid identity for greater than $80 \%$ of the length and an $e$ value $<1 \times 10^{-200}$. For each apparent ortholog, we used ProbCons (Do 2005), a probabilistic consistency algorithm that combines sum-of-pairs scoring and HMM-derived posterior probabilities, to produce a consensus alignment for all orthologs of a gene. For each gene, we performed a model test to determine the best amino acid substitution model. We then constructed individual trees for each protein sequence using RAXML. RAXML is a maximum likelihood-based tool for large phylogenetic trees, and was optimized for running on our computers (Stamatakis 2004, 2006). A majority rules consensus tree was created from all of these individual trees for individual loci using the program Consense within the Phylip package. Consense was then used to create a majority rules consensus tree from phylogenies for all 2,400 loci. In order to display branch lengths on the phylogeny in Figure 1A, we chose a subset of loci whose phylogenetic patterns matched that of the consensus tree of all conserved genes (locus numbers in the P. syringae pv. phaseolicola $1448 \mathrm{a}$ genome: PSPPH_0035, PSPPH_0196, PSPPH_0405, PSPPH_ 0450, PSPPH_0737, PSPPH_1378, PSPPH_1507, PSPPH_ 2368, PSPPH_2957, PSPPH_4280, PSPPH_4340, and PSPPH_ 4623), concatenated these sequences together, aligned with ClustalX, and created a Bayesian phylogeny using Mr. Bayes 3.1.2. To create a phylogeny for the bean species, we obtained sequences of the matK gene from Phaseolus vulgaris (GenBank number EU196765.1), G. $\max (\mathrm{AF} 142700.1)$, and $V$. radiata (JN008226.1), with Desmodium psilocarpum (AY386896.1) as an outgroup. Once sequences were aligned with ClustalX, a Bayesian phylogeny was created using Mr. Bayes 3.1.2.

Table 2. Plasmids

\begin{tabular}{|c|c|c|c|}
\hline Plasmid & Description & Antibiotics $^{\mathrm{a}}$ & Reference, source \\
\hline MTN1907 & Gateway destination vector for making clean deletions in $P$. syringae & $\mathrm{Tet}^{\mathrm{r}}, \mathrm{Kan}^{\mathrm{r}}, \mathrm{Cam}^{\mathrm{r}}, \mathrm{Suc}^{\mathrm{s}}$ & This article \\
\hline pDONR207 & Gateway entry vector from Invitrogen & $\mathrm{Gent}^{\mathrm{r}}, \mathrm{Cam}^{\mathrm{r}}$ & Invitrogen $^{\mathrm{b}}$ \\
\hline MTN1970-2 & $3^{\prime}$ Untranslated region of Arabidopsis HSP18.2 in pDONR207 & Gent $^{\mathrm{r}}$ & This article \\
\hline pDAB255 & avrpto open reading frame (ORF) with stop codon in pDONR207 & Gent $^{\mathrm{r}}$ & This article \\
\hline pDAB238 & efe ORF with stop codon in pDONR207 & Gent $^{r}$ & This article \\
\hline pDAB281 & IaaL ORF with stop codon in pDONR207 & Gent $^{\mathrm{r}}$ & This article \\
\hline MTN1382 & hopH1 ORF with stop codon in pDONR207 & Gent $^{r}$ & This article \\
\hline pDAB059 & hopZ1 ORF with stop codon in pDONR207 & Gent $^{r}$ & This article \\
\hline pDAB283 & shcM/hopM1 ORF with stop codon in pDONR207 & Gent $^{\mathrm{r}}$ & This article \\
\hline pDAB061 & hopCl ORF with stop codon in pDONR207 & Gent $^{r}$ & This article \\
\hline pDAB261 & avrB2 ORF with stop codon in pDONR207 & Gent $^{r}$ & This article \\
\hline pDAB262 & avrB4-1 ORF with stop codon in pDONR207 & Gent $^{r}$ & This article \\
\hline pDAB249 & hopAW1 ORF with stop codon in pDONR207 & Gent $^{r}$ & This article \\
\hline pDAB285 & hopQ1 ORF with stop codon in pDONR207 & Gent $^{r}$ & This article \\
\hline pDAB336 & hopAY1 ORF with stop codon in pDONR207 & Gent $^{r}$ & This article \\
\hline pDAB297 & hopAF1 ORF with stop codon in pDONR207 & Gent $^{\mathrm{r}}$ & This article \\
\hline pDAB282 & shcV/hopV1 ORF with stop codon in pDONR207 & Gent $^{r}$ & This article \\
\hline pDAB263 & hopAB1 ORF with stop codon in pDONR207 & Gent $^{\mathrm{r}}$ & This article \\
\hline pDAB253 & avrRps4 ORF in pDONR207 & Gent $^{\mathrm{r}}$ & This article \\
\hline pBV226 & Gateway destination vector with expression driven by $n p t I I$ promoter & $\operatorname{Tet}^{r}, \operatorname{Cam}^{\mathrm{r}}$ & Vinatzer et al. 2006 \\
\hline pDAB256 & avrpto ORF with stop codon in $\mathrm{pBV} 226$ & $\operatorname{Tet}^{r}$ & This article \\
\hline pDAB245 & efe ORF with stop codon in $\mathrm{pBV} 226$ & Tet $^{\mathrm{r}}$ & This article \\
\hline pDAB363 & IaaL ORF with stop codon in pBV226 & Tet $^{\mathrm{r}}$ & This article \\
\hline pDAB267 & hopH1 ORF with stop codon in pBV226 & Tet $^{r}$ & This article \\
\hline pDAB272 & hopZ1 ORF with stop codon in pBV226 & Tet $^{r}$ & This article \\
\hline pDAB289 & shcM/hopM1 ORF with stop codon in pBV226 & Tet $^{\mathrm{r}}$ & This article \\
\hline pDAB268 & hopCl ORF with stop codon in pBV226 & Tet $^{\mathrm{r}}$ & This article \\
\hline pDAB296 & MTN1970-2 EV construct in pBV226 & Tet $^{\mathrm{r}}$ & This article \\
\hline pDAB269 & avrB2 ORF with stop codon in pBV226 & Tet $^{r}$ & This article \\
\hline pDAB270 & avrB4-1 ORF with stop codon in $\mathrm{pBV} 226$ & Tet $^{\mathrm{r}}$ & This article \\
\hline pDAB250 & hopAW1 ORF with stop codon in pBV226 & Tet $^{\mathrm{r}}$ & This article \\
\hline pDAB287 & hopQ1 ORF with stop codon in $\mathrm{pBV} 226$ & Tet $^{\mathrm{r}}$ & This article \\
\hline pDAB339 & hopAY1 ORF with stop codon in pBV226 & $\operatorname{Tet}^{\mathrm{r}}$ & This article \\
\hline pDAB341 & hopAF1 ORF with stop codon in pBV226 & Tet $^{\mathrm{r}}$ & This article \\
\hline pDAB286 & shcV/hopV1 ORF with stop codon in pBV226 & $\mathrm{Tet}^{\mathrm{r}}$ & This article \\
\hline pDAB271 & hopAB1 ORF with stop codon in pBV226 & Tet $^{\mathrm{r}}$ & This article \\
\hline pDAB254 & avrRps4 ORF with stop codon in pBV226 & $\operatorname{Tet}^{\mathrm{r}}$ & This article \\
\hline SMPgy5172 & avrpto gene with $h r p$-box promoter and no stop codon in pDONR207 & Gent $^{\mathrm{r}}$ & This article \\
\hline pDAB081 & shcM/hopM1 gene with $h r p$-box promoter and no stop codon in pDONR207 & Gent $^{\mathrm{r}}$ & This article \\
\hline SMPgy5168 & hopC1 gene with $h r p$-box promoter and no stop codon in pDONR207 & Gent $^{\mathrm{r}}$ & This article \\
\hline MTN366 & avrB2 gene with $h r p$-box promoter and no stop codon in pDONR207 & Gent $^{r}$ & This article \\
\hline pJC531 & Gateway destination vector based off of pBBR1-MCS2 no promoter & $\mathrm{Kan}^{\mathrm{r}}, \mathrm{Cam}^{\mathrm{r}}$ & Chang et al. 2005 \\
\hline pDAB040 & avrpto gene with hrp-box promoter and no stop codon in pJC531 & $\operatorname{Kan}^{\mathrm{r}}$ & This article \\
\hline pDAB 151 & shcM/hopM1 gene with hrp-box promoter and no stop codon in pJC531 & $\mathrm{Kan}^{\mathrm{r}}$ & This article \\
\hline pDAB039 & hopC1 gene with $h r p$-box promoter and no stop codon in pJC531 & $\mathrm{Kan}^{\mathrm{r}}$ & This article \\
\hline pDAB334 & MTN1970-2 EV construct in pJC531 & $\mathrm{Kan}^{\mathrm{r}}$ & This article \\
\hline pDAB49 & avrB2 gene with $h r p$-box promoter and no stop codon in pJC531 & $\mathrm{Kan}^{\mathrm{r}}$ & This article \\
\hline
\end{tabular}

${ }^{\mathrm{a}} \mathrm{Tet}^{\mathrm{r}}, \mathrm{Kan}^{\mathrm{r}}, \mathrm{Cam}^{\mathrm{r}}$, and Gent ${ }^{\mathrm{r}}=$ resistance to tetracycline, kanamycin, chloramphenicol, and gentamycin; Suc ${ }^{\mathrm{s}}=$ susceptible to sucrose.

b Invitrogen, Carlsbad, CA, U.S.A. 
Comparison of virulence genes

across $P$. syringae pv. phaseolicola 1448 a,

$P$. syringae pv. glycinea $\mathrm{R} 4$, and

\section{$P$. syringae pv. phaseolicola 1644R.}

We searched the draft genome sequence of $P$. syringae pv. phaseolicola $1644 \mathrm{R}$ for virulence genes by tBLASTn using protein sequences of known T3E and toxin pathways as queries (same list as given by Baltrus and associates [2011]). There were no cutoffs used for this initial search, and all potential hits were further confirmed manually. When only fragments of T3E genes could be identified within the draft genome assembly, completeness of these loci was gauged by using SOAP ( $\mathrm{Li}$ et al. 2008) to align Illumina reads to the most closely related allele of each virulence gene, with sequences verified by hand. Truncations within candidate virulence genes were confirmed by targeted Sanger sequencing. Additionally, $P$. syringae $\mathrm{pv}$. phaseolicola $1644 \mathrm{R}$-specific proteins were bioinformatically screened for translocation potential using the SIEVE server (McDermott et al. 2011). If a duplicated member of a T3E family was absent (i.e., avrB4-2 in P. syringae pv. phaseolicola $1644 \mathrm{R}$ ) or there was only an allelic variant of a T3E family, these specific alleles were considered to be absent.

\section{Growth curves and pod inoculation.}

Pod inoculation was done as described by Tsiamis and associates (2000). Briefly, fresh bean pods (before seed clearly developed) were harvested from plants grown under greenhouse conditions and pricked with toothpicks that had been dipped in a $10 \mathrm{mM} \mathrm{MgCl}$ solution containing bacteria at an optical density at $600 \mathrm{~nm}\left(\mathrm{OD}_{600}\right)$ of 0.5 . Pods were kept under continuous light and moderate humidity for 3 days, after which symptoms were photographed.

To measure bacterial growth in planta, French bean and soybean were grown in a growth chamber under long-day conditions (18 h of light and $6 \mathrm{~h}$ of darkness) while mung bean were grown in the greenhouse under similar light conditions. Growth conditions differ across bean species because we found that mung bean plants grown in the greenhouse were able to tolerate hand inoculation whereas those grown in the growth chamber under conditions used for the other legume species were easily crushed. Experiments for Figure 5A and 5 also took place under greenhouse conditions. All bacterial growth measurements on all plant species were performed on primary leaves from 2 -week-old plants. In each case, bacteria were grown overnight in liquid cultures, centrifuged, rinsed with $10 \mathrm{mM} \mathrm{MgCl}$, and resuspended in $10 \mathrm{mM} \mathrm{MgCl}_{2}$ at $\mathrm{OD}_{600}=0.0001$ (approximately $10^{4}$ cells $/ \mathrm{ml}$ ). Bacterial suspensions were inoculated into leaves using a blunt-end syringe in the afternoon (between 2:00 and 6:00 p.m., lights out at approximately 10:00 p.m. in both growth chambers and greenhouses). Four independent replicates of inoculum population size were measured for each strain within each experiment. For ease of comparison across strains within figures, and because day 0 bacterial population sizes were largely indistinguishable within most experiments, population sizes for inoculum are listed in Supplementary Table S1. In order to conserve plants, day 0 bacterial population sizes were measured from the inoculum for all experiments but the $h r p L$ and $h r c C$ analyses; levels in planta are roughly 50- to 100-fold lower than in the inoculum. Bacterial populations were measured after 4 days of growth within French bean and soybean and after 5 days of growth in mung bean because these were the days that showed maximum levels of growth for each specific pathogen in pilot experiments (data not shown). Four cores $\left(1 \mathrm{~cm}^{2}\right)$ were taken on each half of a leaf, with two total leaves per plant sampled (16 cores total, four independent measurements per plant). At least three independent experiments were performed per isolate, except that only two experiments were measured for Figure 5A and C. Data for each experiment were statistically explored by analysis of variance, with isolate as a fixed factor, experiment as a random factor, and plant as a random factor nested within isolate and experiment. If there was a significant effect of isolate in the model, means were compared by post hoc analysis using Tukey's highly significant difference and an $\alpha$ value of 0.05 .

\section{ACKNOWLEDGMENTS}

Funding was provided by National Institute of Health (NIH) grant GM066025 and Department of Energy Basic Energy Sciences grant 95ER20187 to J. L. Dangl, an NIH National Research Service Ruth Kirchstein Award GM082279-01 and startup funds from the University of Arizona to D. A. Baltrus, and from the Arnold and Mabel Beckmann foundation to S. Biswas. J. L. Dangl is an Investigator of the Howard Hughes Medical Institute. We thank C. Jones for technical support with genome assembly and processing; P. Miecskowski, H. Kelkar, and J. Walsh of the UNC-CH HTS core for technical assistance; A. Jones for providing the pLVC-D plasmid; G. Beattie for the P. syringae B728a hrpL mutant; and J. Taylor (NVRS-Wellesbourne, retired) for providing historical background on isolates from his $P$. syringae pv. phaseolicola collection.

\section{LITERATURE CITED}

Abramovitch, R. B., Anderson, J. C., and Martin, G. B. 2006. Bacterial elicitation and evasion of plant innate immunity. Nat. Rev. Mol. Cell Biol. 7:601-611.

Almeida, N. F., Yan, S., Lindeberg, M., Studholme, D. J., Schneider, D. J., Condon, B., Liu, H., Viana, C. J., Warren, A., Evans, C., Kemen, E., Maclean, D., Angot, A., Martin, G. B., Jones, J. D., Collmer, A. Setubal, J. C., and Vinatzer, B. A. 2009. A draft genome sequence of Pseudomonas syringae pv. tomato T1 reveals a type III effector repertoire significantly divergent from that of Pseudomonas syringae pv. tomato DC3000. Mol. Plant-Microbe Interact. 22:52-62.

Arnold, D. L., Jackson, R. W., Fillingham, A. J., Goss, S. C., Taylor, J. D., Mansfield, J. W., and Vivian, A. 2001. Highly conserved sequences flank avirulence genes: Isolation of novel avirulence genes from $\mathrm{Pseu}$ domonas syringae pv. pisi. Microbiology 147:1171-1182.

Arnold, D. L., Lovell, H. C., Jackson, R. W., and Mansfield, J. W. 2011 Pseudomonas syringae pv. phaseolicola: From 'has bean' to supermodel. Mol. Plant Pathol. 12:617-627.

Baltrus, D. A., Nishimura, M. T., Romanchuk, A., Chang, J. H., Mukhtar, M. S., Cherkis, K., Roach, J., Grant, S. R., Jones, C. D., and Dangl, J. L. 2011. Dynamic evolution of pathogenicity revealed by sequencing and comparative genomics of 19 Pseudomonas syringae isolates. PLoS Pathog. 7:e1002132. Published online

Besemer, J., and Borodovsky, M. 2005. GeneMark: Web software for gene finding in prokaryotes, eukaryotes and viruses. Nucleic Acids Res. 33:W451-W454.

Borhan, M. H., Gunn, N., Cooper, A., Gulden, S., Tör, M., Rimmer, S. R., and Holub, E. B. 2008. WRR4 encodes a TIR-NB-LRR protein that confers broad-spectrum white rust resistance in Arabidopsis thaliana to four physiological races of Albugo candida. Mol. Plant-Microbe Interact. 21:757-768.

Cai, R., Lewis, J., Yan, S., Liu, H., Clarke, C. R., Campanile, F., Almeida, N. F., Studholme, D. J., Lindeberg, M., Schneider, D., Zaccardelli, M., Setubal, J. C., Morales-Lizcano, N. P., Bernal, A., Coaker, G., Baker, C., Bender, C. L., Leman, S., and Vinatzer, B. A. 2011. The plant pathogen Pseudomonas syringae pv. tomato is genetically monomorphic and under strong selection to evade tomato immunity. PLoS Pathog. 7:e1002130. Published online.

Chang, J. H., Urbach, J. M., Law, T. F., Arnold, L. W., Hu, A., Gombar, S. Grant, S. R., Ausubel, F. M., and Dangl, J. L. 2005. A high-throughput, near-saturating screen for type III effector genes from Pseudomonas syringae. Proc. Natl. Acad. Sci. U.S.A. 102:2549-2554.

Cunnac, S., Chakravarthy, S., Kvitko, B. H., Russell, A. B., Martin, G. B., and Collmer, A. 2011. Genetic disassembly and combinatorial reassembly identify a minimal functional repertoire of type III effectors in Pseudomonas syringae. Proc. Natl. Acad. Sci. U.S.A. 108:2975-2980

Delgado-Salinas, A., Bibler, R., and Lavin, M. 2006. Phylogeny of the genus Phaseolus (Leguminosae): A recent diversification in an ancient landscape. Syst. Bot. 31:779-791.

Do, C. B. 2005. ProbCons: Probabilistic consistency-based multiple sequence alignment. Genome Res. 15:330-340.

Fan, J., Crooks, C., and Lamb, C. 2007. High-throughput quantitative lu- 
minescence assay of the growth in planta of Pseudomonas syringae chromosomally tagged with Photorhabdus luminescens luxCDABE. Plant J. 53:393-399.

Ferrante, P., Clarke, C. R., Cavanaugh, K. A., Michelmore, R. W., Buonaurio, R., and Vinatzer, B. A. 2009. Contributions of the effector gene hopQ1-1 to differences in host range between Pseudomonas syringae pv. phaseolicola and P. syringae pv. tabaci. Mol. Plant Pathol. 10:837-842.

Gardan, L., Shafik, H., Belouin, S., Broch, R., Grimont, F., and Grimont, P. A. 1999. DNA relatedness among the pathovars of Pseudomonas syringae and description of Pseudomonas tremae sp. nov. and Pseudomonas cannabina sp. nov. (ex Sutic and Dowson 1959). Int. J. Syst. Bacteriol. 492:469-478.

Gassmann, W., Hinsch, M. E., and Staskawicz, B. J. 1999. The Arabidopsis RPS4 bacterial-resistance gene is a member of the TIR-NBS-LRR family of disease-resistance genes. Plant J. 20:265-277.

Glickmann, E., Gardan, L., Jacquet, S., Hussain, S., Elasri, M., Petit, A., and Dessaux, Y. 1998. Auxin production is a common feature of most pathovars of Pseudomonas syringae. Mol. Plant-Microbe Interact. 11:156-162.

Ham, J. H., Kim, M. G., Lee, S. Y., and Mackey, D. 2007. Layered basal defenses underlie non-host resistance of Arabidopsis to Pseudomonas syringae pv. phaseolicola. Plant J. 51:604-616.

Hirano, S. S., Charkowski, A. O., Collmer, A., Willis, D. K., and Upper, C. D. 1999. Role of the Hrp type III protein secretion system in growth of Pseudomonas syringae pv. syringae B728a on host plants in the field. Proc. Natl. Acad. Sci. U.S.A. 96:9851-9856.

Holt, B. F., Belkhadir, Y., and Dangl, J. L. 2005. Antagonistic control of disease resistance protein stability in the plant immune system. Science 309:929-932.

Hwang, M. S. H., Morgan, R. L., Sarkar, S. F., Wang, P. W., and Guttman, D. S. 2005. Phylogenetic characterization of virulence and resistance phenotypes of Pseudomonas syringae. Appl. Environ. Microbiol. 71:5182-5191.

Joardar, V., Lindeberg, M., Jackson, R. W., Selengut, J., Dodson, R., Brinkac, L. M., Daugherty, S. C., Deboy, R., Durkin, A. S., Giglio, M. G., Madupu, R., Nelson, W. C., Rosovitz, M. J., Sullivan, S., Crabtree, J., Creasy, T., Davidsen, T., Haft, D. H., Zafar, N., Zhou, L., Halpin, R., Holley, T., Khouri, H., Feldblyum, T., White, O., Fraser, C. M., Chatterjee, A. K., Cartinhour, S., Schneider, D. J., Mansfield, J. Collmer, A., and Buell, C. R. 2005. Whole-genome sequence analysis of Pseudomonas syringae pv. phaseolicola 1448A reveals divergence among pathovars in genes involved in virulence and transposition. J. Bacteriol. 187:6488-6498.

Jones, J. D. G., and Dangl, J. L. 2006. The plant immune system. Nature 444:323-329

Kobayashi, D. Y., Tamaki, S. J., and Keen, N. T. 1989. Cloned avirulence genes from the tomato pathogen Pseudomonas syringae pv. tomato confer cultivar specificity on soybean. Proc. Natl. Acad. Sci. U.S.A. 86:157-161.

Lacombe, S. E. V., Rougon-Cardoso, A., Sherwood, E., Peeters, N., Dahlbeck, D., van Esse, H. P., Smoker, M., Rallapalli, G., Thomma, B. P. H. J., Staskawicz, B., Jones, J. D. G., and Zipfel, C. 2010. Interfamily transfer of a plant pattern-recognition receptor confers broad-spectrum bacterial resistance. Nat. Biotechnol. 28:365-369.

Li, R., Li, Y., Kristiansen, K., and Wang, J. 2008. SOAP: Short oligonucleotide alignment program. Bioinformatics 24:713-714.

Li, R., Zhu, H., Ruan, J., Qian, W., Fang, X., Shi, Z., Li, Y., Li, S., Shan, G., Kristiansen, K., Li, S., Yang, H., Wang, J., and Wang, J. 2010. De novo assembly of human genomes with massively parallel short read sequencing. Genome Res. 20:265-272.

Li, X., Lin, H., Zhang, W., Zou, Y., Zhang, J., Tang, X., and Zhou, J.-M 2005. Flagellin induces innate immunity in nonhost interactions that is suppressed by Pseudomonas syringae effectors. Proc. Natl. Acad. Sci. U.S.A. 102:12990-12995.

Lin, N.-C., and Martin, G. B. 2007. Pto- and Prf-mediated recognition of AvrPto and AvrPtoB restricts the ability of diverse Pseudomonas syringae pathovars to infect tomato. Mol. Plant-Microbe Interact. 20:806815 .

Lindeberg, M., Cunnac, S., and Collmer, A. 2009. The evolution of Pseudomonas syringae host specificity and type III effector repertoires. Mol. Plant Pathol. 10:767-775.

Lorang, J., Shen, H., and Kobayashi, D. 1994. avrA and avrE in Pseudomonas syringae pv. tomato PT23 play a role in virulence on tomato plants. Mol. Plant-Microbe Interact. 7:508-515.

Marco, M. L., Legac, J., and Lindow, S. E. 2005. Pseudomonas syringae genes induced during colonization of leaf surfaces. Environ. Microbiol. 7:1379-1391.

Marques, A., Corbiere, R., Gardan, L., Tourte, C., Manceau, C., Taylor, J., and Samson, R. 2000. Multiphasic approach for the identification of the different classification levels of Pseudomonas savastanoi pv. phaseolicola. Eur. J. Plant Pathol. 106:715-734.

Mazzola, M., and White, F. F. 1994. A mutation in the indole-3-acetic acid biosynthesis pathway of Pseudomonas syringae pv. syringae affects growth in Phaseolus vulgaris and syringomycin production. J. Bacteriol. 176:1374-1382.

McClean, P., Lavin, M., Gepts, P., and Jackson, S. 2008. Phaseolus vulgaris: A diploid model for soybean. Pages 55-78 in: Soybean Genomics. Springer, Berlin.

McDermott, J., Corrigan, A., and Peterson, E. 2011. Computational prediction of type III and IV secreted effectors in gram-negative bacteria. Infect. Immun. 79:23-32.

Mellersh, D. G., and Heath, M. C. 2003. An investigation into the involvement of defense signaling pathways in components of the nonhost resistance of Arabidopsis thaliana to rust fungi also reveals a model system for studying rust fungal compatibility. Mol. Plant-Microbe Interact. 16:398-404.

Morris, C. E., Sands, D. C., Vanneste, J. L., Montarry, J., Oakley, B., Guilbaud, C., and Glaux, C. 2010. Inferring the evolutionary history of the plant pathogen Pseudomonas syringae from its biogeography in headwaters of rivers in North America, Europe, and New Zealand. mBio 1:e00107-00110-e00107-00120. Published online.

Mysore, K. S., and Ryu, C.-M. 2004. Nonhost resistance: How much do we know? Trends Plant Sci. 9:97-104.

Ortiz-Martín, I., Macho, A. P., Lambersten, L., Ramos, C., and Beuzón, C.R. 2006. Suicide vectors for antibiotic marker exchange and rapid generation of multiple knockout mutants by allelic exchange in gramnegative bacteria. J. Microbiol. Methods 67:395-407.

Ortiz-Martín, I., Thwaites, R., Macho, A. P., Mansfield, J. W., and Beuzón, C. R. 2010. Positive regulation of the Hrp type III secretion system in Pseudomonas syringae pv. phaseolicola. Mol. Plant-Microbe Interact. 23:665-681.

Patil, S. S., Hayward, A., and Emmons, R. 1974. An ultraviolet-induced nontoxigenic mutant of Pseudomonas phaseolicola of altered pathogenicity. Phytopathology 64:590-595.

Perchepied, L., Kroj, T., Tronchet, M., Loudet, O., and Roby, D. 2006. Natural variation in partial resistance to Pseudomonas syringae is controlled by two major QTLs in Arabidopsis thaliana. PLoS ONE 1:e123. Published online.

Qi, M., Wang, D., Bradley, C. A., and Zhao, Y. 2011. Genome sequence analyses of Pseudomonas savastanoi pv. glycinea and subtractive hybridization-based comparative genomics with nine pseudomonads. PLoS ONE 6:e16451. Published online.

Rico, A., and Preston, G. M. 2008. Pseudomonas syringae pv. tomato DC3000 uses constitutive and apoplast-induced nutrient assimilation pathways to catabolize nutrients that are abundant in the tomato apoplast. Mol. Plant-Microbe Interact. 21:269-282.

Roine, E., Wei, W., Yuan, J., Nurmiaho-Lassila, E. L., Kalkkinen, N., Romantschuk, M., and He, S. Y. 1997. Hrp pilus: An hrp-dependent bacterial surface appendage produced by Pseudomonas syringae pv. tomato DC3000. Proc. Natl. Acad. Sci. U.S.A. 94:3459-3464.

Schulze-Lefert, P., and Panstruga, R. 2011. A molecular evolutionary concept connecting nonhost resistance, pathogen host range, and pathogen speciation. Trends Plant Sci. 16:117-125.

Shan, L., He, P., Li, J., Heese, A., Peck, S. C., Nürnberger, T., Martin, G. B., and Sheen, J. 2008. Bacterial effectors target the common signaling partner BAK1 to disrupt multiple MAMP receptor-signaling complexes and impede plant immunity. Cell Host Microbe 4:17-27.

Sohn, K. H., Saucet, S. B., Clarke, C. R., Vinatzer, B. A., O’Brien, H. E., Guttman, D. S., and Jones, J. D. G. 2011. HopAS1 recognition significantly contributes to Arabidopsis nonhost resistance to Pseudomonas syringae pathogens. New Phytol. 193:58-66.

Song, J., Bradeen, J. M., Naess, S. K., Raasch, J. A., Wielgus, S. M., Haberlach, G. T., Liu, J., Kuang, H., Austin-Phillips, S., Buell, C. R., Helgeson, J. P., and Jiang, J. 2003. Gene RB cloned from Solanum bulbocastanum confers broad spectrum resistance to potato late blight. Proc. Natl. Acad. Sci. U.S.A. 100:9128-9133.

Stamatakis, A. 2004. RAxML-III: A fast program for maximum likelihood-based inference of large phylogenetic trees. Bioinformatics 21:456-463.

Stamatakis, A. 2006. RAxML-VI-HPC: Maximum likelihood-based phylogenetic analyses with thousands of taxa and mixed models. Bioinformatics 22:2688-2690.

Staskawicz, B. J., Dahlbeck, D., and Keen, N. T. 1984. Cloned avirulence gene of Pseudomonas syringae pv. glycinea determines race-specific incompatibility on Glycine $\max$ (L.) Merr. Proc. Natl. Acad. Sci. U.S.A. 81:6024-6028.

Stevens, C., Bennett, M. A., Athanassopoulos, E., Tsiamis, G., Taylor, J. D., and Mansfield, J. W. 1998. Sequence variations in alleles of the avirulence gene avrPphE.R2 from Pseudomonas syringae pv. phaseo- 
licola lead to loss of recognition of the AvrPphE protein within bean cells and a gain in cultivar-specific virulence. Mol. Microbiol. 29:165177.

Studholme, D. J. 2011. Application of high-throughput genome sequencing to intrapathovar variation in Pseudomonas syringae. Mol. Plant Pathol. 12:829-838

Tai, T. H., Dahlbeck, D., Clark, E. T., Gajiwala, P., Pasion, R., Whalen, M. C., Stall, R. E., and Staskawicz, B. J. 1999. Expression of the Bs2 pepper gene confers resistance to bacterial spot disease in tomato. Proc. Natl. Acad. Sci. U.S.A. 96:14153-14158.

Takeuchi, K., Taguchi, F., Inagaki, Y., Toyoda, K., Shiraishi, T., and Ichinose, Y. 2003. Flagellin glycosylation island in Pseudomonas syringae pv. glycinea and its role in host specificity. J. Bacteriol. 185:66586665.

Taylor, J., Teverson, D., and Allen, D. 1996. Identification and origin of races of Pseudomonas syringae pv. phaseolicola from Africa and other bean growing areas. Plant Pathol. 45:469-478.

Tsiamis, G., Mansfield, J. W., Hockenhull, R., Jackson, R. W., Sesma, A., Athanassopoulos, E., Bennett, M. A., Stevens, C., Vivian, A., Taylor, J. D., and Murillo, J. 2000. Cultivar-specific avirulence and virulence functions assigned to avrPphF in Pseudomonas syringae pv. phaseolicola, the cause of bean halo-blight disease. EMBO (Eur. Mol. Biol. Organ.) J. 19:3204-3214.

Vera Cruz, C. M., Bai, J., Ona, I., Leung, H., Nelson, R. J., Mew, T. W. and Leach, J. E. 2000. Predicting durability of a disease resistance gene based on an assessment of the fitness loss and epidemiological consequences of avirulence gene mutation. Proc. Natl. Acad. Sci. U.S.A. 97:13500-13505.

Vinatzer, B. A., Teitzel, G. M., Lee, M.-W., Jelenska, J., Hotton, S., Fairfax, K., Jenrette, J., and Greenberg, J. T. 2006. The type III effector repertoire of Pseudomonas syringae pv. syringae B728a and its role in survival and disease on host and non-host plants. Mol. Microbiol. 62:2644.

Warren, R. F., Merritt, P. M., Holub, E., and Innes, R. W. 1999. Identifica- tion of three putative signal transduction genes involved in $\mathrm{R}$ genespecified disease resistance in Arabidopsis. Genetics 152:401-412.

Wei, C.-F., Kvitko, B. H., Shimizu, R., Crabill, E., Alfano, J. R., Lin, N.C., Martin, G. B., Huang, H.-C., and Collmer, A. 2007. A Pseudomonas syringae pv. tomato DC3000 mutant lacking the type III effector HopQ1-1 is able to cause disease in the model plant Nicotiana benthamiana. Plant J. 51:32-46.

Weingart, H., Ullrich, H., Geider, K., and Völksch, B. 2001. The role of ethylene production in virulence of Pseudomonas syringae pvs. glycinea and phaseolicola. Phytopathology 91:511-518.

Wen, C., Tang, X., Su, Z., and Zhou, J. 2010. Effector-triggered and pathogen-associated molecular pattern-triggered immunity differentially contribute to basal resistance to Pseudomonas syringae. Mol. Plant-Microbe Interact. 23:940-948.

Wroblewski, T., Caldwell, K. S., Piskurewicz, U., Cavanaugh, K. A., Xu, H., Kozik, A., Ochoa, O., McHale, L. K., Lahre, K., Jelenska, J., Castillo, J. A., Blumenthal, D., Vinatzer, B. A., Greenberg, J. T., and Michelmore, R. W. 2009. Comparative large-scale analysis of interactions between several crop species and the effector repertoires from multiple pathovars of Pseudomonas and Ralstonia. Plant Physiol. 150:1733-1749.

Xiang, T., Zong, N., Zou, Y., Wu, Y., Zhang, J., Xing, W., Li, Y., Tang, X. Zhu, L., Chai, J., and Zhou, J.-M. 2008. Pseudomonas syringae effector AvrPto blocks innate immunity by targeting receptor kinases. Curr. Biol. 18:74-80

Zumaquero, A., Macho, A. P., Rufián, J. S., and Beuzón, C. R. 2010. Analysis of the role of the type III effector inventory of Pseudomonas syringae pv. phaseolicola $1448 \mathrm{a}$ in interaction with the plant. J. Bacteriol. 192:4474-4488.

\section{AUTHOR-RECOMMENDED INTERNET RESOURCES}

Phylip package: evolution.genetics.washington.edu/phylip.htm Mr. Bayes database: mrbayes.csit.fsu.edu 